\title{
Prevalence and Antibiotic Resistance of Campylobacter spp. in Urban and Rural Black-Headed Gulls Chroicocephalus ridibundus
}

\author{
Piotr Indykiewicz, ${ }^{1}$ Małgorzata Andrzejewska, ${ }^{2}$ Piotr Minias, ${ }^{3}$ Dorota Śpica, ${ }^{2}$ \\ and Jarosław Kowalski ${ }^{4}$ \\ ${ }^{1}$ Department of Biology and Animal Environment Landscaping, Bydgoszcz University of Science and Technology, Mazowiecka 28, 85-084 Bydgoszcz, Poland \\ ${ }^{2}$ Department of Hygiene, Epidemiology, Ergonomy and Postgraduate Education, Nicolaus Copernicus University, M. Curie-Skłodowskiej 9, 85-094 \\ Bydgoszcz, Poland \\ ${ }^{3}$ Department of Biodiversity Studies and Bioeducation, Faculty of Biology and Environmental Protection, University of Łódź, Banacha 1/3, 90-237 Łódź, Poland \\ ${ }^{4}$ Gorzewo 7, 09-200 Sierpc, Poland
}

\begin{abstract}
We investigate the role of black-headed gulls (Chroicocephalus ridibundus), an omnivorous species that is among the most likely wild bird candidates for transmission of zoonotic agents, as a potential reservoir of Campylobacter spp. Colonies with different anthropogenic pressures were studied to examine differences in exposure to sources of Campylobacter between rural and urban birds. We recorded Campylobacter spp. in $4.87 \%$ of adult black-headed gulls and $2.22 \%$ of their chicks after analysing 1036 cloacal swabs collected over two breeding seasons in three colonies in northern Poland. Campylobacter jejuni was found most frequently (85.72\%), and Campylobacter lari and Campylobacter coli were much scarcer. Prevalence of Campylobacter did not differ significantly between black-headed gulls breeding in urban (4.27\%) and rural (3.80\%) habitats. Almost all isolates from chicks and adults were susceptible to azithromycin (97.62\%) and erythromycin (95.24\%), but fewer to tetracycline $(50.00 \%)$ and ciprofloxacin $(47.62 \%)$. Campylobacter prevalence was unrelated to the date of sampling. Our study indicates that black-headed gulls are carriers of resistant to antibiotics Campylobacter and they can contaminate natural waterbodies with their faeces, which poses a threat to human and farm animal health.
\end{abstract}

Keywords: Antibiotic resistance, Birds, Black-headed gull, Campylobacteriosis, Urbanization, Zoonoses

\section{INTRODUCTION}

Campylobacter and Salmonella spp. are leading causes of zoonotic stomach and intestinal infections in humans, both in developing and developed countries, and the frequency of these infections is increasing even in countries with

Published online: September 3, 2021

Correspondence to: Małgorzata Andrzejewska, e-mail: m.andrzejewska@cm.umk.pl efficient public healthcare systems (WHO 1980, Oberhelman and Taylor 2000; Friedman et al. 2001; Baker et al. 2007; Olson et al. 2008). Increasing prevalence of campylobacteriosis in South America, Europe and Australia is alarming, and data from Africa, Asia and the Middle East show that it is endemic in these areas, especially among children (Kaakoush et al. 2015). The European Food Safety Authority (EFSA) and the European Centre for Disease Prevention and Control (ECDC) report that campylobacteriosis affects up to 246000 residents of the European 
Union (EU) per year (EFSA 2018), but the real number of annual Campylobacter infections is estimated as ca 9 million a year (EFSA 2011a, Havelaar et al. 2009). Since 2005, the total number of campylobacteriosis cases in the EU has exceeded the number of reported salmonellosis cases, and it is still rising in some EU countries (EFSA 2011b, 2018). Campylobacteriosis affects people of all ages, but infections are most frequent in children younger than five (Kaakoush et al. 2015) and city dwellers older than 50 (Nichols et al. 2012). Workers at abattoirs, mainly of poultry, as well as veterinarians, breeders of poultry, cattle and pigs, and ornithologists, are especially exposed to infections (Jones 2001; Abulreesh et al. 2007; Humphrey et al. 2007; Silva et al. 2011; WHO 2013). Two autoimmune neurological disorders, Guillain-Barre and Miller-Fisher syndromes, have been associated with $C$. jejuni infections (Ang et al. 2001; van Doorn et al. 2008). The EFSA has estimated that Campylobacter infections cause work absences in the EU costing about $€ 2.4$ billion a year (EFSA 2011ab) and in the USA about $\$ 1.6$ billion (Scharff 2011). Taking all this into account, campylobacteriosis is considered one of the most widespread and important infectious diseases that poses an increasing threat to global health (Kaakoush et al. 2015).

Despite the threat to human health, Campylobacter epidemiology is not yet fully understood, and epidemiological pathways leading to humans are incompletely recognized (Ramos et al. 2010; Kaakoush et al. 2015). We also do not know much about Campylobacter infections in wild animals, such as the duration of infection, if Campylobacter produce clinical or subclinical patterns, or if infected animals gain temporary or general immunity (Broman et al. 2002). Campylobacter are widely distributed in nature, and the main risk factors for humans are international travel; food of animal origin (especially milk and poultry-Hänninen et al. 2003; Baker et al. 2006; Gu et al. 2009; Acke et al. 2011; Kaakoush et al. 2015; EFSA, 2017); direct contact with animal hosts and natural waters polluted by bird faeces (Humphrey et al. 2007; Kaakoush et al. 2015). The digestive systems of wild and domesticated birds and mammals are the main reservoirs of Campylobacter. Extensive evidence exists of wild birds being directly responsible for causes of zoonotic gastrointestinal infections in humans (Gardner et al. 2011; Rutledge et al. 2013; Kaakoush et al. 2015).

Gulls are among birds frequently tested for public health reasons, because they often forage at rubbish dumps or near inlets to sewage plants (Smith and Carlile 1993a; Hatch 1996; Belant 1997; Clark et al. 2013; Egunez et al. 2018). Also, population sizes of many gull species in Eur- ope, North America and Australia have increased considerably over the past few decades (Smith and Carlile 1993b; Vidal et al. 1998; Perriman and Lalas 2012; Washburn et al. 2016), which may pose an increasing epidemiological threat.

Our study aimed to assess Campylobacter prevalence in the black-headed gull Chroicocephalus ridibundus, a common species associated mainly with inland freshwater habitats. Black-headed gulls are migratory and long-lived (van Dijk et al. 2012), and they also exhibit strong philopatry (Peron et al. 2010) and may return to the same colonies over many years, even when breeding habitats undergo unfavourable changes (Burger 1979). The blackheaded gull is an omnivorous and opportunistic species, which searches for food in natural habitats, such as seacoasts and the banks of lakes and rivers, in arable areas and urban habitats. Here, we specifically aimed to determine: (i) prevalence of Campylobacter spp. in the Polish population of black-headed gulls in association with age and type of habitat (urban versus rural), (ii) prevalence of Campylobacter in the social partners and offspring of infected individuals and (iii) resistance of recorded Campylobacter isolates to selected antibiotics.

\section{Material ANd Methods}

\section{Study Site and General Field Procedures}

We studied black-headed gulls in three breeding colonies located in north-central Poland. Two urban colonies were situated ca $15.5 \mathrm{~km}$ apart on the opposite sides of Bydgoszcz city (ca. 400000 inhabitants). One site was located in an industrial zone (Bydg-IND), the other in a recreational area (Bydg-REC). The Bydg-IND colony was located on a small island $\left(53^{\circ} 7^{\prime} 7.9^{\prime \prime} \mathrm{N}, 18^{\circ} 6^{\prime} 19.1^{\prime \prime} \mathrm{E}\right)$ in a natural bay of the Brda River. The Bydg-REC colony $\left(53^{\circ} 9^{\prime} 51.5^{\prime \prime} \mathrm{N}, 18^{\circ} 2^{\prime} 12.1^{\prime \prime} \mathrm{E}\right)$ occurred in a small reservoir abutting the zoological garden and a vast recreational area. The third (rural) colony was located on an island at $\mathrm{Ku}$ sowo lake $\left(53^{\circ} 15^{\prime} 0.3^{\prime \prime} \mathrm{N}, 18^{\circ} 8^{\prime} 28.8^{\prime \prime} \mathrm{E}\right)$, a natural reservoir surrounded by farmland. In 2015-2016, 330-350 pairs of black-headed gulls bred in the Bydg-IND colony, 120 pairs in Bydg-REC and 880-1200 pairs in Kusowo. The extent of anthropogenic pressure, physiographic characteristics of the areas surrounding the breeding sites and detailed information about the study area were described by $\mathrm{Ki}$ towski et al. (2017) and Indykiewicz et al. (2018a). 
For the purpose of Campylobacter detection, we collected cloacal swabs from 718 adult (older than 2 years) black-headed gulls and 318 of their chicks aged 7-21 days. All captured birds were individually marked to avoid repeated sampling of the same individuals. Sample sizes were similar for urban $(n=473$ swabs $)$ and rural $(n=563$ swabs) colonies (Table 1). All samples were collected between 19 April and 16 June. The median sampling dates were 12 May and 06 June for adults and chicks, respectively. The total number of sampling events was 31 (16 in 2015 and 15 in 2016) for Bydg-IND, 11 (only 2016) for Bydg-REC and 38 (12 in 2015 and 26 in 2016) for Kusowo. Samples were stored in sterile Amies charcoal transport medium (Transwab ${ }^{\circledR}$ ENT Amies) in a portable fridge at $1-4{ }^{\circ} \mathrm{C}$. Within $4 \mathrm{~h}$ from collection, we brought the swabs to the laboratory, where they immediately underwent the isolation procedure.

\section{Campylobacter Isolation and Identification}

Isolation of Campylobacter bacteria was based on the method described previously by French et al. (2009), in which the material requires initial incubation in $3 \mathrm{ml}$ of Bolton broth (Oxoid) in conditions with reduced oxygen supply $\left(85 \% \mathrm{~N}_{2}, 10 \% \mathrm{CO}_{2}, 5 \% \mathrm{O}_{2}\right.$-Generbox microaer, BioMerieux) in temperature $42{ }^{\circ} \mathrm{C}$ for $48 \mathrm{~h}$. Next $10 \mu \mathrm{l}$ of the enrichment culture was streaked onto agar plates (Charcoal Cefoperazone Desoxycholate Agar plates-
mCCDA, Oxoid) under the conditions described above. Grown colonies were evaluated for morphology and subject to biochemical tests. The catalase and oxidase reactions were performed using available tests (Oxoid). The colonies recognized as presumptive Campylobacter spp. were retained for further study.

Confirmation of isolates to Campylobacter genus and species identification was conducted with multiplex PCR. The presence of Campylobacter target genes was determined with primers set together in Table 1 . The conditions of DNA amplification reaction used in our study were described by Yamazaki-Matsune et al. (2007). Bacterial DNA was isolated from cultures grown on Columbia agar with $5 \%$ of sheep blood after microaerophilic incubation for $24 \mathrm{~h}$ (de Lamballerie et al. 1992). PCR amplification was performed in a mixture of $5 \mu$ of DreamTaq PCR Buffer (Fermentas), $0.5 \mu \mathrm{l}$ of dNTPs (10 mM Fermentas), $1 \mu \mathrm{l}$ of each primer $(1 \mu \mathrm{M}), 1 \mathrm{U}$ of Dream Taq DNA polymerase (Fermentas) and $1 \mu \mathrm{l}$ of template DNA, and then, the final volume was adjusted to $25 \mu \mathrm{l}$.

We performed DNA amplification in a Tpersonal thermal cycler (Biometra) and then analysed PCR products by electrophoresis in $1.5 \%$ agarose gel. DNA bands were visualised by staining the samples with Midori Green DNA Stain (Nippon Genetics) and photographed using the IG/ LE InGenius L documentation system (Syngene). PCR amplicons were compared with DNA length markers (Fermentas).

Table 1. PCR Primers used for Campylobacter Detection

\begin{tabular}{lll}
\hline Species & Primer & Sequence $\left(5^{\prime}\right.$ to $\left.3^{\prime}\right)$ \\
\hline Genus Campylobacter & C412F & $5^{\prime}$-GGATGACACTTTTCGGAGC-3' \\
C. hyointestinalis & C1228R & $5^{\prime}$-CATTGTAGCACGTGTGTC-3' \\
& HYO1F & $5^{\prime}$-ATAATCTAGGTGAGAATCCTAG-3' \\
C. coli & HYOFET23SR & $5^{\prime}$-GCTTCGCATAGCTAACAT-3' \\
& CC18F & $5^{\prime}$-GGTATGATTTCTACAAAGCGAG-3' \\
C. fetus & CC519R & $5^{\prime}$-ATAAAAGACTATCGTCGCGTG-3' \\
& MG3F & $5^{\prime}$-GGTAGCCGCAGCTGCTAAGAT-3' \\
C. lari & CF359R & $5^{\prime}$-AGCCAGTAACGCATATTATAGTAG-3' \\
C. jejuni & CLF & $5^{\prime}$-TAGAGAGATAGCAAAAGAGA-3' \\
& CLR & $5^{\prime}$-TACACATAATAATCCCACCC-3' \\
C. upsaliensis & C-1 & $5^{\prime}$-CAAATAAAGTTAGAGGTAGAATGT-3' \\
& C-3 & $5^{\prime}$-CCATAAGCACTAGCTAGCTGAT-3' \\
\hline
\end{tabular}




\section{Antimicrobial Susceptibility Testing}

We determined the susceptibility of Campylobacter isolates to clinically important antimicrobials: erythromycin, azithromycin, tetracycline and ciprofloxacin. E-test (AB Biodisk) was applied on Mueller-Hinton agar supplemented with 5\% defibrinated horse blood (Oxoid). The plates, inoculated with test strain, were incubated at $37{ }^{\circ} \mathrm{C}$ for $48 \mathrm{~h}$ under microaerophilic conditions. MIC values were determined according to Clinical and Laboratory Standards Institute's guidelines for the Enterobacteriaceae family (CLSI 2008). Thresholds for Campylobacter resistance were set as follows: erythromycin $32 \mu \mathrm{g} / \mathrm{mL}$, tetracycline $16 \mu \mathrm{g} /$ $\mathrm{mL}$, azithromycin $8 \mu \mathrm{g} / \mathrm{mL}$ and ciprofloxacin $4 \mu \mathrm{g} / \mathrm{mL}$. We used C. jejuni ATCC 33,560 and C. coli ATTC 33,559 as reference strains.

\section{Statistical Analyses}

Prevalence of Campylobacter in black-headed gulls was analysed with generalized linear models (GLMs) for the binomial distribution of a response variable (0-no Campylobacter recorded, 1-Campylobacter recorded). The effect of colony location (urban vs. rural) was tested separately for adults and nestlings. To test for the effect of year, we used data exclusively from adult birds (sampled in both years, 2015-2016), while to test or the effect of age (adult $v s$. nestling), we used data exclusively from 2016 (both ages sampled). Sampling date was entered as a covariate in each model. Similar models were run for the occurrence of resistant Campylobacter isolates (0-non-resistant strain, 1 -resistant strain). All models were run using the lme4 package (Bates et al. 2015) for R (R Development Core Team 2013). We used the car package (Fox and Weisberg 2011) to determine Wald $\mathrm{Chi}^{2}$ (W) statistics and $\mathrm{P}$ values for all predictors.

\section{Results}

We detected Campylobacter spp. in 35 of 718 (4.87\%) samples from adult black-headed gulls and in 7 of 318 (2.22\%) samples from chicks (Table 2). We found no significant difference in Campylobacter prevalence between the two age categories $(W=0.04, d f=1, P=0.84)$. At the age of 1-2 weeks, there were five chicks positive for Campylobacter, and at the age over 2 weeks-only two individuals. C. jejuni was most frequently identified in positive samples
(85.72\%. $n=42$ ), whereas C. lari and C. coli were recorded significantly less frequently ( $7.14 \%$ each). Prevalence of Campylobacter in black-headed gulls from urban and rural habitats did not differ significantly, neither in adults $(4.56 \%$ vs $5.20 \% ; W=0.02, d f=1, P=0.88)$ nor nestlings $(0.99 \%$ vs $2.77 \% ; W=1.77, d f=1, P=0.18)$. However, we found that Campylobacter prevalence in adult gulls differed significantly between the two breeding seasons ( $W=4.12, d f=1, P=0.042$ ). Specifically, prevalence was higher in 2015 than in 2016, and this difference occurred in both study colonies that were sampled in both seasons (Kusowo: 6.74\% and 3.59\% in 2015 and 2016, respectively; Bydg-IND: $7.14 \%$ and $2.04 \%$ in 2015 and 2016, respectively). We found no support for an association between Campylobacter prevalence and sampling date in adults ( $W=0.11, d f=1, P=0.74)$, but in nestlings, this relationship was only marginally non-significant $(W=3.32$, $d f=1, P=0.068)$, indicating a trend for a decreasing prevalence with date $(\beta=-0.059 \pm 0.029)$.

Out of 35 adults positive for Campylobacter, 27 individuals had their social partners also examined for Campylobacter occurrence. We found no simultaneous infection with these bacteria in both partners in any pair. Almost all birds (97.1\%) in which we found Campylobacter in rural habitats bred at the periphery of their breeding colony; only one infected gull nested in the centre of a colony.

Almost all Campylobacter isolates from black-headed gulls were susceptible to azithromycin (97.62\%) and erythromycin $(95.24 \%)$. Half of isolates were resistant to tetracycline $(50.00 \%)$ and ciprofloxacin $(47.62 \%)$ (Table 3). Almost one-third of Campylobacter isolates were resistant to two antibiotics (ciprofloxacin and tetracycline-12/42, or erythromycin and tetracycline-2/42), and, exceptionally, to three antibiotics (azithromycin, erythromycin and tetracycline-1/42). Isolates resistant to tetracycline occurred more frequently in adults than chicks ( $W=4.01, d f=1, P=0.045)$, but we found no such difference in the Campylobacter resistant to ciprofloxacin ( $W=0.65, d f=1, P=0.42$ ). Similarly, the proportion of isolates resistant to tetracycline was significantly higher in 2015 than in $2016(61.9 \%$ vs $21.4 \% ; W=6.37, d f=1$, $P=0.011)$, but we found no such difference for ciprofloxacin ( $W=0.40, d f=1, P=0.53$ ). The proportion of isolates resistant to tetracycline and ciprofloxacin did not differ between adult black-headed gulls from urban and rural colonies (tetracycline: $W=0.19, d f=1, P=0.66$; ciprofloxacin: $W=0.13, d f=1, P=0.72$ ). Also, we found 
Table 2. Prevalence of different Campylobacter Species in Cloacal Swabs Collected from Adult (ad.) and Chick (pull.) Black-headed Gulls in 2015-2016 at Urban (U) and Rural (R) Habitats in Northern Poland.

\begin{tabular}{|c|c|c|c|c|c|c|c|c|c|}
\hline \multirow[t]{2}{*}{ Year } & \multirow[t]{2}{*}{ Breeding colony } & \multicolumn{2}{|c|}{ N samples } & \multicolumn{2}{|c|}{ C. jejuni } & \multicolumn{2}{|c|}{ C. lari } & \multicolumn{2}{|c|}{ C. coli } \\
\hline & & ad & pull & $a d$ & pull & ad & pull & ad & pull \\
\hline \multirow[t]{2}{*}{2015} & Kusowo (R) & 179 & - & 10 & - & 2 & - & - & - \\
\hline & Bydg-IND (U) & 132 & - & 9 & - & - & - & - & - \\
\hline \multirow[t]{4}{*}{2016} & Kusowo (R) & 167 & 217 & 5 & 5 & - & - & 1 & 1 \\
\hline & Bydg-IND (U) & 146 & 101 & 3 & - & - & - & - & 1 \\
\hline & Bydg-REC (U) & 94 & - & 4 & - & 1 & - & - & - \\
\hline & TOTAL & 718 & 318 & 31 & 5 & 3 & - & 1 & 2 \\
\hline
\end{tabular}

Table 3. Antibiotic resistance of Campylobacter Strains Isolated from Cloacal Swabs of Black-headed Gull Chicks and Adults in in Northern Poland 2015-2016.

\begin{tabular}{|c|c|c|c|c|c|c|c|c|}
\hline \multirow[t]{2}{*}{ Campylobacter ( $\mathrm{N}$ of isolates) } & \multicolumn{2}{|c|}{ Azithromycin } & \multicolumn{2}{|c|}{ Erythromycin } & \multicolumn{2}{|c|}{ Tetracycline } & \multicolumn{2}{|c|}{ Ciprofloxacin } \\
\hline & $\mathrm{N}$ & $\%$ & $\mathrm{~N}$ & $\%$ & $\mathrm{~N}$ & $\%$ & $\mathrm{~N}$ & $\%$ \\
\hline C. jejuni (36) & 0 & 0.00 & 1 & 2.77 & 22 & 61.11 & 20 & 55.55 \\
\hline C. lari (4) & 0 & 0.00 & 0 & 0,00 & 1 & 25.00 & 2 & 50.00 \\
\hline C. $\operatorname{coli}(2)$ & 1 & 50.00 & 1 & 50.00 & 2 & 100.00 & 1 & 50.00 \\
\hline
\end{tabular}

no association between prevalence of Campylobacter isolates resistant to these antibiotics and sampling date (tetracycline: $W=1.19, d f=1, \quad P=0.28$; ciprofloxacin: $W=0.01, d f=1, P=0.92)$.

\section{Discussion}

Current knowledge on the prevalence of Campylobacter in black-headed gulls is mostly based on material collected during winter or migration (Kapperud and Rosef 1983; Broman et al. 2002; Moore et al. 2002; Cody, 2015). As far as we are aware, adults and chicks from the same breeding colonies have never been studied. Similarly, studies of black-headed gulls breeding across urbanization gradient are also lacking. Here, we documented prevalence of Campylobacter spp. in chicks $(2.2 \%)$ and adults $(4.9 \%)$ from the same colonies in northern Poland. Also, for the first time, we compared Campylobacter prevalence in adult black-headed gulls from colonies located within and outside urban areas. Campylobacter prevalence in our study populations was similar to that recorded in post-breeding season in the Great Britain (2.1-3.5\%-Cody et al. 2015) and Northern Ireland (7.1\%-Moore et al. 2002), but was lower than in Sweden (13.2-42.9\%-Kapperud and Rosef 1983; 27.9-36.2\%-Broman et al. 2002) and Czech Republic (63\%—Sixl et al. 1997). In our study, we found similar prevalence of Campylobacter between adults and chicks, which is no surprising taking into account feeding method-food is regurgitated by the adults for the chicks to eat. Horizontal transmission between chicks within the breeding or between chicks from different nests when they are older and free to move within the colony cannot be ruled out. On the other hands, we recorded no cases of horizontal transmission of Campylobacter between social mates. It could be explained by the fact that pairs only physically interact during copulation (which is very brief and usually lasts for a short time, mainly in the pre-laying period). Lack of horizontal transmission may suggest that Campylobacter is more easily transmitted from adults to offspring rather than between adults, but further research is needed to provide more empirical support for this hypothesis.

The number of studies on the prevalence of Campylobacter spp. in gulls chicks is limited. Infection of broiler flocks by $C$. jejuni usually starts from the third week and increases with age (Hermans et al. 2011; Sahin et al. 2003). 
In our study, out of seven positive for Campylobacter chicks, five were at the age of 7 to 14 days, and only two individuals were aged between 16-21 days. This result contradicts previous studies of Sahin et al., (2003) where active immune responses to Campylobacter in broilers chicks occurred earlier and more strongly in birds infected at 21 days of age than these infected at 3 days of age. Further studies need to be performed to explain age-related sensitivity to Campylobacter colonization in gulls chicks.

Despite our expectations, we found similar prevalence of Campylobacter in black-headed gulls breeding in urban $(4.3 \%)$ and rural $(3.8 \%)$ habitats. Our previous study has shown that birds from the urban colony in Bydgoszcz forage mainly on the territory of the city and in its immediate vicinity, while birds from non-urban colonies tend to avoid this type of habitat during foraging flights (Jakubas et al. 2020). We predicted that urban birds may be exposed to more sources of Campylobacter than rural birds, e.g. the remains of food in rubbish bins and disposal points near human residences, on municipal rubbish dumps and in sewage works. For example, high proportion of anthropogenic food remains in the diet the yellow-legged gull Larus michahellis was associated with higher prevalence of Campylobacter spp. (Ramos et al. 2009). On the other hands, rural gulls that mostly forage in farmland may be more exposed to interactions with domestic and farm animals, which could produce similar levels of Campylobacter prevalence in urban and rural habitats. In fact, several studies on humans showed higher campylobacteriosis rate in rural areas than in the cities (Strachan et al. 2009; Lévesque et al. 2013). Further studies, ideally supported by diet composition, are needed to better explain the lack of significant differences in Campylobacter prevalence among the three colonies.

While studying black-headed gulls in rural areas $(\mathrm{Ku}-$ sowo), we noted that almost all individuals infected with Campylobacter $(97.1 \%)$ located their nests at the periphery of the breeding colony. This corresponds with results of our earlier studies in the same colony, where we found evidence for higher physiological condition of birds breeding in the colony centre (Indykiewicz et al. 2018b). Thus, it seems likely that central pairs may also be more resistant to pathogens than peripheral low-quality pairs. Finally, individuals with more efficient immune system have a greater chance of occupying a high-quality territory in the centre of the colony, and individuals with lower resistance may deliberately avoid the densities in the centre that should promote higher transmission rate of pathogens.

Intra-annual dynamics of human campylobacteriosis may be primarily associated with the composition of breeding, rather than migratory or wintering, avifauna. Infections in temperate countries of the Northern Hemisphere, such as Wales, Denmark, Finland and Sweden, peak between early May and mid-July week of the year (Nylen et al. 2002; Cody et al. 2015). Prevalence of Campylobacter in broiler flocks peaks in the early summer months (Boysen et al. 2011) in contradiction to lambs and dairy cattle which had two peaks per year, in approximately spring and autumn (Stanley et al. 1998ab), but it coincides with breeding season of most avian species, including black-headed gulls. This might suggest that wildlife plays an important role in spreading Campylobacter bacteria to humans, and this hypothesis has received non-negligible empirical support. For example, Cody et al. (2015) suggested that in Oxfordshire county alone wild birds might cause campylobacteriosis in as many as 10000 humans a year. Despite this evidence, the prevailing opinion is that wild birds play a relatively minor role in the epidemiology of $C$. jejuni infections in humans. The crucial argument to support this thesis is based in the genotype and the serotype differences between the strains of $C$. jejuni isolated from man, broiler chicks, pigs and wild birds (Rosef et al. 1985; Whelan et al. 1988; Petersen et al. 2001; Broman et al. 2002).

Although most people with $C$. jejuni infection can successfully recover without specific medical treatment, in many countries infections are, by default, treated with antibiotics, mostly macrolides in combination with azithromycin or aminoglycosides in severe cases (Moore et al. 2002; Bolinger and Kathariou, 2017). Antibiotics are increasingly dispensed to humans in a prophylactic way, for example, to prevent travel diarrhoea, for which fluoroquinolones and tetracyclines are often prescribed (Guerrant et al. 2001). The common use of antibiotics in human therapy increases the number of Campylobacter strains resistant to these medicines (Kaakoush et al. 2015), and this process is further enhanced by veterinary use of antibiotics, where only $20 \%$ are administered to cure infections, while the remaining $80 \%$ are used prophylactically and to stimulate livestock growth, a practice banned in the EU in 2006 (Chiesa et al. 2015). Tetracyclines, fluoroquinolones, macrolides and sulphonamides are most often used in veterinary practice (EMA, 2016), and a large proportion 
(10-90\%) of those are later excreted by animals into the environment in an unchanged form or as active metabolites (Sturini et al. 2014). Therefore, as much as $44.1 \%$ of $C$. jejuni isolates from animals, mostly from poultry, is resistant to ciprofloxacin, and $34.1 \%$ of the isolates are resistant to tetracycline in the EU (EFSA 2014). In our study population of black-headed gulls, the resistance to these two antibiotics was slightly higher $(55.6 \%$ and $51.2 \%$, respectively). In black-headed gulls chicks from Moravia, Czech Republic, all Campylobacter isolates (100\%) were resistant to tetracycline and to ampicillin (Sixl et al. 1997). C. jejuni isolated in Iberian coast from yellow-legged gulls (Larus michahellis), resistant to ciprofloxacin (67\%) and tetracycline (34\%) were previously described by Lourdes et al. (2017). In Jurinović et al.'s study (2020), all C. jejuni isolated from gulls in Croatia (yellow-legged gull, blackheaded gull, caspian gull—Larus cachinanns, herring gullL. argentatus and common gull-L. canus were) found to be susceptible to erythromycin, while $2.0 \%$ of isolates were found to be resistant to gentamicin and $46 \%$ to tetracycline.

Antibiotic resistance of Campylobacter strains in other species of wild birds largely varies. For example, a study of the White Stork Ciconia ciconia in Poland found that 19.0\% and $52.4 \%$ of C. jejuni isolates were resistant to tetracycline and ciprofloxacin, respectively (Szczepańska et al. 2015). In the long-eared owl, Asio otus in Sweden, the resistance to ciprofloxacin was found in $11.1 \%$ of isolates (Waldenström et al. 2005), while in the house crow Corvus splendens and pigeons from the Serdang region in Malaysia the resistance of Campylobacter to tetracycline recorded in $33.3 \%$ of isolates (Mustaffa et al. 2014).

In conclusion, the results of our study indicate that black-headed gulls harbour Campylobacter spp. More importantly, we confirmed that black-headed gulls are carriers of antibiotic-resistant Campylobacter, which may pose a threat to human and farm animal health. We also underline the need of further studies to assess the role of black-head gull in Campylobacter spp. epidemiology. Further studies comprising genetic relatedness of Campylobacter isolates from human, wild birds and water sources are needed as they can confirm environmental transmission of Campylobacter by polluting artificial and natural waterbodies, soil and plants with their faeces.

\section{ACKNOWLEDGEMENTS}

We thank anonymous reviewers for constructive comments on the earlier draft of the manuscript.

\section{Declarations}

CONFLICT OF INTEREST The authors report no conflict of interests.

ETHICAL APPROVAL The study was conducted in accordance with the current laws of Poland under the permission of the Bioethical Commission for Animal Welfare and the Regional Environmental Protection Directorate in Bydgoszcz.

\section{Open Access}

This article is licensed under a Creative Commons Attribution 4.0 International License, which permits use, sharing, adaptation, distribution and reproduction in any medium or format, as long as you give appropriate credit to the original author(s) and the source, provide a link to the Creative Commons licence, and indicate if changes were made. The images or other third party material in this article are included in the article's Creative Commons licence, unless indicated otherwise in a credit line to the material. If material is not included in the article's Creative Commons licence and your intended use is not permitted by statutory regulation or exceeds the permitted use, you will need to obtain permission directly from the copyright holder. To view a copy of this licence, visit http://creativec ommons.org/licenses/by/4.0/.

\section{REFERENCES}

Abulreesh HH, Goulder R, Scott GW (2007) Wild birds and human pathogens in the context of ringing and migration. Ringing \& Migratio 23:193-200. https://doi.org/10.1080/03078698.2007. 9674363

Acke E, Carroll C, O’Leary A, McGill K, Kelly L, Lawlor A, Madden RH, Moran L, Scates P, McNamara E, Moore JE, Jones BR, Fanning S, Whyte P (2011) Genotypic characterization and cluster analysis of Campylobacter jejuni isolates from domestic pets, human clinical cases and retail food. Irish Veterinary Journal 64:6. http://www.irishvetjournal.org/content/64/1/6

Ang CW, De Klerk MA, Endtz HP, Jacobs BC, Laman JD, Van Der Meché FGA, van Doorn PA (2001) Guillain-Barré syndromeand Miller Fisher syndrome-associated Campylobacter jejuni lipopolysaccharides induce anti- $\mathrm{GM}_{1}$ and anti-GQ $\mathrm{G}_{1 \mathrm{~b}}$ antibodies 
in rabbits. Infection and Immunity 69(4):2462-2469. https:// doi.org/10.1128/IAI.69.4.2462-2469.2001

Baker M, Wilson N, Ikram R, Chambers S, Shoemack P, Cook G (2006) Regulation of chicken contamination is urgently needed to control New Zealand's serious campylobacteriosis epidemic. New Zealand Medical Journal 119(1243):U2264

Baker MG, Sneyd E, Wilson NA (2007) Is the major increase in notified campylobacteriosis in New Zealand real? Epidemiology and Infection 135(1):63-170 https://www.ncbi.nlm.nih.gov/pm c/articles/PMC2870549/

Bates D, Maechler M, Bolker B, Walker S (2015) Fitting linear mixed-effects models using lme4. Journal of Statistical Software 67:1-48 https://arxiv.org/abs/1406.5823

Belant JL (1997) Gulls in urban environments: landscape-level management to reduce conflict. Landscape and Urban Planning 38:245-258. https://doi.org/10.1016/S0169-2046(97)00037-6

Bolinger H, Kathariu S (2017) The Current State of Macrolide Resistance in Campylobacter spp.: Trends and Impacts of Resistance Mechanisms. Applied and Environmental Microbiology 83(12):e0416-17 https://aem.asm.org/content/83/12/e00416 $-17$

Boysen L, Vigre H, Rosenquist H (2011) Seasonal influence on the prevalence of thermotolerant Campylobacter in retail broiler meat in Denmark. Food Microbiol. 28(5):1028-1032. https:// doi.org/10.1016/j.fm.2011.02.010

Broman T, Palmgren H, Bergström S, Sellin M, Waldenström J, Danielsson-Tham ML, Olsen B (2002) Campylobacter jejuni in black-headed gulls (Larus ridibundus): prevalence, genotypes, and influence on C. jejuni epidemiology. Journal of clinical microbiology 40(12):4594-4602. https://jcm.asm.org/content/40/ $12 / 4594$

Burger J (1979) Competition and predation: Herring Gull vs. Laughing Gull. Condor 81:1269-1277 https://sora.unm.edu/site s/default/files/journals/condor/v081n03/p0269-p0277.pdf

Chiesa L, Nobile M, Arioli F, Britti D, Trutic N, Pavlovic R, Panseri S (2015) Determination of veterinary antibiotics in bovine urine by liquid chromatography-tandem mass spectrometry. Food Chemistry 185:7-15. https://doi.org/10.1016/ j.foodchem.2015.03.098

Clark DE, Koenen KKG, Mackenzie KG, Pereira JW, Destefano S (2013) Stainless-steel wires exclude gulls from a wastewater treatment plant. Journal American Water Works Association 105(10):609-618. https://doi.org/10.5942/jawwa.2013.105.0118

CLSI (2008) Performance Standards for Antimicrobial Disk and Dilution Susceptibility Tests for Bacteria Isolated from Animals; Approved Standard, 3rd edn. CLSI document M31-A3. Wayne, PA: Clinical and Laboratory Standards Institute. https://www.db t.univr.it/documenti/OccorrenzaIns/matdid/matdid485539.pdf

Cody AJ, McCarthy ND, Bray JE, Wimalarathna HLM, Colles FM, van Rensburg MJJ, Dingle KE, Waldenström J, Maiden MCJ (2015) Wild bird-associated Campylobacter jejuni isolates are a consistent source of human disease, in Oxfordshire United Kingdom. Environmental Microbiology Reports 7(5):782-788. https://doi.org/10.1111/1758-2229.12314

EFSA (2011a) Scientific opinion on Campylobacter in broiler meat production: Control options and performance objectives and/or targets at different stages of the food chain. EFSA Journal 9:2105. http://www.adiveter.com/ftp_public/A4150411.pdf

EFSA (2011b) The European Union Summary Report on Trends and Sources of Zoonoses, Zoonotic Agents and Food-borne Outbreaks in 2009. EFSA Journal 9(3):2090. https://doi.org/10. 2903/j.efsa.2011.2090
EFSA (2014) The European Union Summary Report on antimicrobial resistance in zoonotic and indicator bacteria from humans, animals and food in 2012. EFSA Journal 12(3):3590 h ttps://www.efsa.europa.eu/en/efsajournal/pub/3590

EFSA (2018) The European Union Summary Report on Trends and Sources of Zoonoses, Zoonotic Agents and Food-borne Outbreaks in 2017. EFSA Journal 2018;16(12):5500 https://ww w.efsa.europa.eu/en/efsajournal/pub/5500

Egunez A, Zorrozua N, Aldalur A, Herrero A, Arizaga J (2018) Local use of landfills by a yellow-legged gull population suggests distance-dependent resource exploitation. Journal of Avian Biology 49(2) https://doi.org/10.1111/jav.01455

EMA - European Medicine Agency (2016) Sales of veterinary antimicrobial agents in 29 European countries in 2014. Trends from 2011 to 2014. Sixth ESVAC report. 14 October 2016. EMA //61769/2016. Veterinary Medicines Division. https://www.em a.europa.eu/en/documents/report/sixth-esvac-report-sales-veter inary-antimicrobial-agents-29-european-countries-2014_en.pdf

Fox JIn: Weisberg S (editors) (2011) An R companion to applied regression, 2nd ed., Thousand Oaks: Sage

French NP, Midwinter A, Holland B, Collins-Emerson J, Pattison R, Colles F, Carter P (2009) Molecular epidemiology of Campylobacter jejuni isolates from wild-bird fecal material in children's playgrounds. Applied and Environmental Microbiology 75(3):779-83 https://aem.asm.org/content/75/3/779

Friedman CR, Neimann J, Wegener HC, Tauxe RV (2001) Epidemiology of Campylobacter jejuni infections in the United States and other industrialized nations. In: Nachamkin I, Blaser MJ (editors), Campylobacter Washington, DC: ASM Press, pp 121-138. https://doi.org/10.1128/9781555815554.ch09

Gardner TJ, Fitzgerald C, Xavier C, Klein R, Pruckle J, Stroika S, McLaughlin JB (2011) Outbreak of campylobacteriosis associatedwith consumption of raw peas. Clinical Infectious Diseases 53(1):26-32. https://doi.org/10.1093/cid/cir249

Gu W, Siletzky RM, Wright S, Islam M, Kathariou S (2009) Antimicrobial susceptibility profiles and strain type diversity of Campylobacter jejuni isolates from turkeys in eastern North Carolina. Applied and Environtal Microbiology 75:474-482. htt ps://aem.asm.org/content/75/2/474

Guerrant RL, van Gilder T, Steiner TS, Thielman NM, Slutsker L, Tauxe RV, Hennessy T, Griffin PM, DuPont H, Sack RB, Tarr P, Neill M, Nachamkin I, Reller LB, Osterholm MT, Bennish ML, Pickering LK (2001) Practice guidelines for the management of infectious diarrhea. Clinical Infectious Diseases 32(3):331-351. https://doi.org/10.1086/318514

Hatch JJ (1996) Threats to public health from gulls (Laridae). International Journal of Environmental Health Research 6:5-16. https://doi.org/10.1080/09603129609356867

Hänninen ML, Haajanen H, Pummi T, Wermundsen K, Katila ML, Sarkkinen H, Miettinen I, Rautelin H (2003) Detection and typing of Campylobacter jejuni and Campylobacter coli and analysis of indicator organisms in three waterborne outbreaks in Finland. Applied and Environtal Microbiology 69:1391-1396. h ttps://www.ncbi.nlm.nih.gov/pmc/articles/PMC150068/

Hermans D, Van Deun K, Van Immerseel F, Heyndrickx M, Haesebrouck F, Pasmans F (2011) Colonization factors of Campylobacter jejuni in the chicken gut. Vet Res. 42(1): 82. Published online 2011 Jun 29. https://doi.org/10.1186/1297-9716-42-82.

Havelaar AH, Ivarsson S, Löfdahl M (2009) Nauta MJ (2013) Estimating the true incidence of campylobacteriosis and salmonellosis in the European Union. Epidemiology and Infection 141(2):293302. https://doi.org/10.1017/S0950268812000568 
Humphrey T, O’Brien S, Madsen M (2007) Campylobacters as zoonotic pathogens: a food production perspective. International Journal of Food Microbiology 117:237-257. https://doi.org/ 10.1016/j.ijfoodmicro.2007.01.006

Indykiewicz P, Podlaszczuk P, Janiszewska A, Minias P (2018) Extensive gene flow along the urban-rural gradient in a migratory colonial bird. Journal of Avian Biology 2018:e1723. https://doi.org/10.1111/jav.01723

Indykiewicz P, Podlaszczuk P, Kamiński M, Włodarczyk R, Minias P (2018b) Costs and benefits of central versus peripheral nestin $1 \mathrm{~g}$ in a colony of black-headed gulls. Ibis. https://doi.org/10. 1111/ibi.12689.

Jakubas D, Indykiewicz P, Minias P, Kowalski J, Iciek T (2020) Inter-colony variation in flight characteristics of black-headed gulls Chroicocephalus ridibundus during the incubating period. Ecology and Evolution 10:5489-5505

Jones K (2001) Campylobacters in water, sewage and the environment. Journal of Applied Microbiology 90:68-79. https:// doi.org/10.1046/j.1365-2672.2001.01355.x

Jurinović L, Duvnjak S, Kompes G, Šoprek S, Šimpraga BF, Mikulić M, Humski A (2020) Occurrence of Campylobacter jejuni in Gulls Feeding on Zagreb Rubbish Tip, Croatia; Their Diversity and Antimicrobial Susceptibility in Perspective with Human and Broiler Isolates. Pathogens 24;9(9):E695. https://doi. org/10.3390/pathogens9090695

Kaakoush NO, Castaño-Rodríguez N, Mitchell HM, Man SM (2015) Global epidemiology of Campylobacter infection. Clinical Microbiology Reviews 28:687-720. https://cmr.asm.org/conte $\mathrm{nt} / 28 / 3 / 687$

Kapperud G, Rosef O (1983) Avian wildlife reservoir of Campylobacter fetus subsp. jejuni, Yersinia spp., and Salmonella spp. in Norway. Applied and Environmental Microbiology 45(2):375380. https://www.cabi.org/ISC/abstract/19832221033

Kitowski I, Indykiewicz P, Wiącek D, Jakubas D (2017) Intraclutch and inter-colony variability in concentrations of elements in eggshells of the black-headed gull Chroicocephalus ridibundus in N Poland. Environmental Science and Pollution Research 24(11):10341-10353. https://link.springer.com/article/10.1007\% 2Fs11356-017-8635-Z

Lévesque S, Fournier E, Carrier N, Frost E, Arbeit RD, Michaud S (2013) Campylobacteriosis in Urban versus Rural Areas: A Case-Case Study Integrated with Molecular Typing to Validate Risk Factors and to Attribute Sources of Infection. PLOS ONE 8(12):e83731. https://doi.org/10.1371/journal.pone.0083731

Lourdes MG, Ramos R, Cerdà-Cuéllar M (2017) Antimicrobial Resistance of Salmonella Serovars and Campylobacter spp. Isolated from an Opportunistic Gull Species, Yellow-legged Gull (Larus michahellis). Journal of Wildlife Diseases 53(1), 148-152. https://doi.org/10.7589/2016-03-051

Moore JE, Gilpin D, Crothers E, Canney A, Kaneko A, Matsuda M (2002) Occurrence of Campylobacter spp. and Cryptosporidium spp. in Seagulls (Larus spp.). Vector-Borne and Zoonotic Diseases 2(2):111-114. https://doi.org/10.1089/153036602321131913

Mustaffa SS, Saleha AA, Jalila A (2014) Occurrence of antibiotic resistant Salmonella and Campylobacter in wild birds. Malaysian Journal of Microbiology 26(2):17-19. https://aem.asm.org/conte $\mathrm{nt} / 75 / 2 / 474$

Nichols GL, Richardson JF, Sheppard SK, Lane C, Sarran C (2012) Campylobacter epidemiology: a descriptive study reviewing 1 million cases in England and Wales between 1989 and 2011. BMJ Open 2012;2:e001179. https://bmjopen.bmj.com/content/ 2/4/e001179
Nylen G, Dunstan F, Palmer SR, Andersson Y, Bager F, Cowden J, Feierl G, Galloway Y, Kapperud G, Megraud F, Molbak K, Petersen LR, Ruutu P (2002) The seasonal distribution of campylobacter infection in nine European countries and New Zealand. Epidemiology and Infection 128(3):383-390. https:// doi.org/10.1017/S0950268802006830

Oberhelman RA, Taylor DN (2000) Campylobacter infections in developing countries. In: Campylobacter, Nachamikin I, Blaser MJ (editors), Washington, DC: ASM Press, pp 139-154. https:// www.ncbi.nlm.nih.gov/pmc/articles/PMC4542018/

Olson CK, Ethelberg S, van Pelt W, Tauxe RV (2008) Epidemiology of Campylobacter jejuni infections in industrialized nations. In: Campylobacter Nachamkin I, Szymanski CM, Blaser MJ (editors), Washington, DC: ASM Press, pp 163-19 http:// www.asmscience.org/content/book/https://doi.org/10.1128/978 1555815554.ch09

Peron G, Lebreton JD, Crochet PA (2010) Breeding dispersal in black-headed gull: the value of familiarity in a contrasted environment. Journal of Animal Ecology 79:317-326. http://ww w.asmscience.org/content/book/. https://doi.org/10.1128/97815 55815554.ch09

Perriman L, Lalas C (2012) Recent increase in population size of red-billed gulls (Larus novaehollandiae scopulinus) at Otago, southern New Zealand. Notornis 59(3):138-147. https://www. notornis.osnz.org.nz/system/files/Perriman\%20\%26\%20Lalas\% 202012.pdf

Petersen L, Nielsen EM, Engberg J, On SLW, Dietz HH (2001) Comparison of genotypes and serotypes of Campylobacter jejuni isolated from Danish wild mammals and birds and from broiler flocks and humans. Applied of Environtal Microbiology 67:31153121. https://aem.asm.org/content/67/7/3115

R Development Core Team (2013) R: a language and environment for statistical computing v. 3.4.1. R Foundation for Statistical Computing, Vienna, Austria https://www.r-project.org/

Ramos R, Ramírez F, Sanpera C, Jover L, Ruiz X (2009) Feeding ecology of yellow-legged gulls Larus michahellis in the western Mediterra nean: a comparative assessment using conventional and isotopic methods. Marine Ecology Progress Series 377:289297

Ramos R, Cerdà-Cuéllar M, Ramírez F, Jover L,and Ruiz X (2010) Influence of Refuse Sites on the Prevalence of Campylobacter spp. and Salmonella Serovars in Seagulls. Appl Environ Microbiol. 2010 May; 76(9): 3052-3056. https://www.ncbi.nlm. nih.gov/pmc/articles/PMC2863452/

Rosef O, Kapperud G, Lauwers S, Gondrosen B (1985) Serotyping of Campylobacter jejuni, Campylobacter coli, and Campylobacter laridis from domestic and wild animals. Applied of Environmental Microbiology 49(6):1507-1510. https://www.ncbi.nlm.ni h.gov/pmc/articles/PMC241755/

Rutledge ME, Siletzky RM, Gu W, Degernes LA, Moorman CE, DePerno CS, Kathariou S (2013) Characterization of Campylobacter from resident Canada geese in an urban environment. Journal of Wildlife Diseases 49(1):1-9. https://doi.org/10.7589/ 2011-10-287

Sahin O, Luo N, Huang S, Zhang Q. (2003) Effect of Campylobacter-specific maternal antibodies on Campylobacter jejuni colonization in young chickens. Appl Environ Microbiol. Sep;69(9):5372-9. https://doi.org/10.1128/aem.69.9.5372-5379. 2003.

Scharff RL (2011) Economic burden from health losses due to foodborne illness in the United States. Journal of Food Protection 75(1):123-131 https://jfoodprotection.org/doi/pdf/https://doi.o rg/10.4315/0362-028X.JFP-11-058 
Silva J, Leite D, Fernandes M, Mena C, Gibbs PA, Teixeira P (2011) Campylobacter spp. as a Foodborne Pathogen: A Review. Frontiers in Microbiology 2:200. https://doi.org/10.3389/fmicb. 2011.00200

Sixl W, Karpísková R, Hubálek Z, Halouzka J, Mikulásková M, Salava J (1997) Campylobacter spp. and Salmonella spp. in black-headed gulls (Larus ridibundus). Central European journal of public health 1(5):24-26. https://www.researchgate.net/publi cation/14067559_Campylobacter_spp_and_Salmonella_spp_i n_black-headed_gulls_Larus_ridibundus

Smith GC, Carlile N (1993a) Food and Feeding Ecology of Breeding Silver Gulls (Larus novaehollandiae) in Urban Australia. Colonial Waterbirds 16(1):9-16. https://www.jstor.org/st able/1521551

Smith GC, Carlile N (1993) Methods for population control within a silver gull colony. Wildlife Research 20:219-226. https:// doi.org/10.1071/WR9930219

Stanley KN, Wallace JS, Currie JE, Diggle PJ, Jones K (1998a) Seasonal variation of thermophilic campylobacters in lambs at slaughter. Journal of Applied Microbiology 84:1111-6. https://doi. org/10.1046/j.1365-2672.1998.00450.x

Stanley KN, Wallace JS, Currie JE, Diggle PJ, Jones K (1998b) The seasonal variation of thermophilic campylobacters in beef cattle, dairy cattle and calves. Journal of Applied Microbiology 85(3):472-80. https://doi.org/10.1046/j.1365-2672.1998.853511. $\mathrm{X}$

Strachan NJ, Gormley FJ, Rotariu O, Ogden ID, Miller G, Dunn GM, Sheppard SK, Dallas JF, Reid TM, Howie H, Maiden MC, Forbes KJ (2009) Attribution of Campylobacter Infections in Northeast Scotland to Specific Sources by Use of Multilocus Sequence Typing. The Journal of Infectious Diseases 199(8):1205-1208. https://doi.org/10.1086/597417

Sturini M, Speltini A, Maraschi F, Pretali L, Profumo A, Fasani E, Albini A (2014) Environmental photochemistry of fluoroquinolones in soil and in aqueous soil suspensions under solar light. Environmental Science and Pollution Research 21(23):13215-13221. https://link.springer.com/article/10.1007\% 2Fs11356-013-2124-9

Szczepańska B, Kamiński P, Andrzejewska M, Śpica D, Kartanas E, Ulrich W, Jerzak L, Kasprzak M, Bocheński M, Klawe JJ (2015) Prevalence, virulence, and antimicrobial resistance of Campylobacter jejuni and Campylobacter coli in white stork Ciconia ciconia in Poland. Foodborne Pathogens and Disease 12(1):2431. https://doi.org/10.1089/fpd.2014.1793

van Dijk K, Oosterhuis R, Middendorp B, Majoor F (2012) New longevity records of Black-headed Gull, with comments on wear and loss of aluminium rings. Dutch Birding 34:20-31. http://fra nkmajoor.nl/PDF/Black-headed_Gull_longevity_aluminium_ri ngs_\%20DB_2012_page20-31.pdf

van Doorn P, Ruts L, Jacobs BC (2008) Clinical features, pathogenesis, and treatment of Guillain-Barre syndrome. Lancet Neurology 7(10):939-950. https://doi.org/10.1016/S14744422(08)70215-1

Vidal E, Medail F, Tatoni T (1998) Is the yellow-legged gull a superabundant bird species in the Mediterranean? Impact on fauna and flora, conservation measures and research priorities. Biodiversity and Conservation 7(8):1013-1026. https://doi.org/ 10.1023/A:1008805030578

Waldenström J, Mevius D, Veldman K, Broman T, Hasselquist D, Olsen B (2005) Antimicrobial Resistance Profiles of Campylobacter jejuni Isolates from Wild Birds in Sweden. Applied and Environmental Microbiology 71(5):2438-2441 https://aem.asm. org/content/71/5/2438

Washburn BE, Elbin SB, Davis C (2016) Historical and Current Population Trends of Herring Gulls (Larus argentatus) and Great Black-Backed Gulls (Larus marinus) in the New York Bight, USA. Waterbirds 39(sp1):74-86. https://digitalcommons. unl.edu/cgi/viewcontent.cgi? article $=2847 \&$ context $=$ icwdm_usd anc

Whelan CD, Monaghan P, Girdwood RW, Fricker CR (1988) The significance of wild birds (Larus sp.) in the epidemiology of Campylobacter infections in humans. Epidemiology \& Infection 101:259-267. https://www.ncbi.nlm.nih.gov/pmc/articles/PM C2249366/

WHO Scientific Working Group (1980) Enteric infections due to Campylobacter, Yersinia, Salmonella, and Shigella. Bulletin of the World Health Organization 58(4):519-537. https://www.ncbi.nl m.nih.gov/pmc/articles/PMC2395930/

WHO (2013) The global view of Campylobacteriosis Report of an expert consultation. Utrecht, Netherlands, 9-11 July 2012, World Health Organization 2013. http://www.who.int/iris/hand le/10665/80751

Yamazaki-Matsune W, Taguchi M, Seto K, Kawahara R, Kawatsu K, Kumeda Y, Kitazato M, Nukina M, Misawa N, Tsukamoto T (2007) Development of a multiplex PCR assay for identification of Campylobacter coli, Campylobacter fetus, Campylobacter hyointestinalis subsp. hyointestinalis, Campylobacter jejuni, Campylobacter lari and Campylobacter upsaliensis. Journal of Medical Microbiology 56:1467-1473. https://doi.org/10.1099/jm m.0.47363-0\#tab2 